\title{
An Archaeology of Remembering: Death, Bereavement and the First World War
}

\author{
Sarah Tarlow
}

\begin{abstract}
Archaeological approaches to death and commemoration which privilege the negotiation of power relationships can underestimate the importance of personal and emotional responses to bereavement and mortality. Remembrance of the dead of the First World War is often understood in terms of the promotion of nationalist ideologies, but emotional factors such as grief and shock were also involved in the shaping of commemorative responses. In this article, responses to the First World War at national, local, and individual levels are considered. I suggest that people select monuments, places and ways of remembering for their power to express intense and personal feelings.
\end{abstract}

They shall not grow old as we that are left grow old Age shall not wither them nor the years condemn At the going down of the sun and in the morning We shall remember them

Lawrence Binyon For the Fallen

The history of the First World War and its casualties still has an emotive resonance in the consciousness of much of the modern world. This article, however, is not primarily about the experience of the men who marched away. It is not about an archaeology of war as such, but an archaeology of remembering. It is about those people, most of whom never experienced the slaughter of the trenches, who experienced bereavement. ${ }^{1}$

The suffering of the bereaved precipitated a crisis of expression, and this article is about the search for an adequate response to the war. I will argue that the expression of personal emotion was brought to a particular crisis by the manner and number of losses sustained in the First World War. Trends which had been underway for some time gathered greater momentum during the war and, as the twentieth century has progressed, the manner and location of remembering the dead has moved from the flamboyantly individual to the intensely personal, from the cemetery to the home. Rather than a fundamental change in attitude to death, as has been maintained by many commentators, I believe this represents a response to a crisis of personal expression.

A study of the material responses to death at the time of the First World War makes the need to consider individual, emotional experience in archaeology strikingly apparent. Explanatory schemes which privilege the negotiation of power relationships fail to account for motivated action at the individual level and undervalue the complexity of human emotional experience.

\section{Archaeology and the emotional self}

Death is not so much the issue here as it is a metonym for a more encompassing argument. It seems to me that we invoke quite often 'sensuality', 'emotion', 'conviction' and the like in social theoretical explanations. We talk about desire for power, about awe before the gods and before kings, about magic as the audacious confrontation of human and natural forces, and about ideological notions of purity and danger being tied to physiological processes. The physical and the emotional are part of our social theoretical discussions just as much as are cold, calculated motives and logics. (Kus 1992, 172) 
A review of archaeological explicatory practices makes nonsense of the notion that emotionless pasts can be written. Archaeological evidence frequently comes from contexts such as burial or settlement. Yet how can we consider death without considering grief, fear and other emotions, the expression of which structures funerary practices? How can we consider the household or community only in terms of control of resources or 'the exchange of women', when there is no concern with affection, loyalty, aspiration - the emotional basis of group identity? We discuss war without considering aggression; ethnicity as an attribute more than as a psychological, emotionally-based construct. ${ }^{2}$ We know, from our own experiences, that emotional responses and psychological conditions are fundamental to every aspect of human practice and interaction - social, political, and economic. A consideration of emotion in the past should not be peripheral, one of many possible but not essential aspects of the past. Emotion is central to so much else of what archaeologists choose to study. Other patterns of human relations which are important to us as archaeologists (relations such as gender and power) are constructed through subjective experience, and emotions such as fear and affection. Archaeological explanations frequently invoke, at least by implication, emotional understandings and responses in the past. The problem with which we are confronted is not so much whether the consideration of 'emotion', 'sensuality' and 'experience' is viable in archaeology, but, since the invocation of such factors is inevitable, how can archaeologists go about the task of making such considerations.

It is not fair to the people of the past, of whom we speak, and whom we represent, to ignore or devalue what was necessarily central to their practices. To concentrate solely on how the consequences of action affected relations of power, when the action in question is the burial of child, for example, is extraordinarily cynical and almost certainly unjust.

As yet, however, there remains considerable resistance to the study of emotion and experience in the academic world; this resistance has much to do with the continuing grip of analytical approaches which centralize dynamics of power. In 1987, Shanks \& Tilley made a programmatic statement of what they felt archaeology should be about (a prescription for being radical)

... a production of texts ... which subvert those archaeologies that would deny the study of material culture as being fundamentally a study of power, the mediation, representation and articula- tion of power strategies through material forms. (Shanks \& Tilley 1987, 208)

Even in 1987, the goal of explaining the mechanics of power in archaeological investigation had an established legitimacy within institutions of academic study, such as university departments and publishing companies. Since 1987, the archaeological consideration of power has become a new orthodoxy in some archaeological circles, notably British prehistory. There is now little political risk in suggesting that the archaeological past was one in which relationships of domination and control were negotiated. The past which we have been offered over the last few years is a past of conflict and dissonance, of competing interests and strategies of representation (see, for example, the papers in Gledhill et al. 1988; Miller \& Tilley 1984; McGuire \& Paynter 1991; Miller et al. 1989). It is one in which the reduction of human relationships to relationships of power is the bottom line of archaeological explanation. It is an aggressive, macho past, in which suggestions that the past contained co-operative endeavour, shared aspirations, sentiment and emotion are considered fey and irresponsible, candyflossing the harsh realities of struggle.

Archaeological discussion of emotion and experience (not 'embodiment' as a set of generalizing and robotic principles, but the sensual, feeling person in the past) is more unsettling. The risk is greater: to express a past which involves passion, fear, grief, love is to risk one's own credibility, to appear soppy, romantic and weak. Emotional responses are held to be incompatible with proper logical thought, and seriously out of place in an academic discipline. Perhaps it is fear for their own credibility which makes academicians shy away from emotion as an area of consideration, choosing instead hard-edged, masculine dynamics such as power relations, technology or economics.

It is not only fear for one's credibility which produces doubts and anxieties about the possibility of considering emotion and subjective experience in the past. Archaeologists feel more comfortable dealing with the consequences of action than with its motivation. In part this is to do with the critique of 'palaeopsychology' (Fritz 1978), which has stressed, in its processual phase, the inaccessibility of minds in the past because, unlike anthropological research, the people studied by archaeologists cannot be asked to explain their behaviour. The post-processual critique of 'palaeopsychology' has centred on the complexity and ultimate irreducibility of human 
behaviour, i.e. even if you could ask a Neolilthic person to explain a certain action, their response would not constitute a conclusive answer (Shanks \& Tilley 1987a, 61-78).

I accept this critique with reservations. As archaeologists we deal with human behaviour all the time. Human behaviour is extremely complex and motivation is multi-faceted. Arrival at any real single truth is never going to be possible, because no such truth exists (Shanks \& Tilley 1987a,b; Hodder 1986). This does not, however, mean that the more complex, mental aspects of human behaviour are not interesting or worthwhile subjects of study. On the contrary. As I have expressed above, an understanding of emotional and experiential aspects of human practice in the past is central to our consideration of other arenas of human practice such as subsistence strategies, burial practices, exchange systems or technologies. Any aspect of material practice is galvanized by human volition. When we hypothesize about social and economic relations and relationships of power, we are necessarily considering the personal and emotional, since these have no abstractable reality and are constituted only through subjective understandings. 'Mind' in the past can only be ignored if one accepts that there is some sort of social and economic reality prior to and separate from the ideological, emotional and mental ways in which it is understood by people. Kristiansen (1984) cites Parker Pearson's 1982 paper as a step towards the 'essential' goal of archaeologists 'to clarify the relationship between social reality and its ideological interpretation'. But ideology is so embedded in 'social reality' that a division between the real world and the ideology by which it is understood is misleading and ultimately untenable (Hodder 1986; Shanks \& Tilley 1987a).

Kus (1992) has outlined the difficulties of writing histories of emotion without taking the essentialist position that emotional responses are universal, and involve responding to the same cues in the same way. This is a problem which has occupied psychologists concerned with the position of emotions in human experience. It is clear that people from different cultures not only respond to different emotional 'cues', but that they also experience different actual feelings. Some cultures, for example, make no distinction between 'sadness' and 'anger' (e.g. English-speaking Ugandans: Heelas 1986, 239) or, like the Tahitians, have no word for an emotion corresponding to 'guilt' (Levy 1984, 219). It appears therefore that the emotional responses we have, their degree of intensity and the way we experience them are cultural rather than instinctive traits. From this, however, we should not take the idea that emotions are 'false' or 'unnatural'. The experience of emotion is no less real for being culturally constructed. In many instances, in fact, emotions can modify or even override biologically driven behaviour, so that sorrow might persuade an individual to take their own life, or compassion can make people risk their own safety in order to help a stranger.

Given that emotional responses are not universal, how can the project of examining emotion in the past be undertaken? To acknowledge the social construction of emotions should assist us in this project. It is because emotions are socially constructed that they should be part of archaeological study. It is also because emotions are socially constructed that they can be amenable to archaeological analysis. Emotions are constructed through practices and ways of communicating, which we see in the archaeological record. If certain emotions correspond with the values of a society - grief at death, fear of ancestors, love of country, for example, then they will be created and recreated through, amongst other things, material practice. It is material practice to which, as archaeologists, we have access.

Leventhal (1980) distinguishes between 'emotional elements' and 'emotional experiences'. He suggests that intrinsic biological properties need to be enriched by cultural meanings before they can constitute emotional experiences. Heelas (1986) also concentrates on difference in what provokes feeling, rather than on how it is experienced. In distinguishing different emotions which appertain to different cultures, however, he validates a constructionist view of emotion, that people neither universally respond to the same emotional 'cues' in the same way, nor is the experience of feeling an emotion the same for all groups. Even within a group or society, emotions can vary according to ethnic identity, gender, age and individual character and psychological makeup. At a personal level, different, or even incompatible emotions can characterize the response of a single individual. That individual will not necessarily be able to explain their own emotions. Given this variability and ambiguity, it is not surprising that scepticism about the project of an archaeology of emotion is expressed.

Even though a complete understanding of the emotional experience of an individual in the past is ultimately denied to us, however, certain emotional values can characterize a group. Furthermore those values, expressed and reproduced through material practice, can be the subject of archaeological 
interpretation. Heelas (1986) explains Levy's (1984) idea that different cultures have different 'hypercognized' emotions which unite a society in common values:

'Love' and 'guilt' for us; 'pressure' for the Rastafarian; 'fear' and 'shyness' for the Chewong;... . 'passion' or liget for the Ilongot ...; 'fear' and 'shame' for the Tahitian . . . all are hypercognised or focal emotions. (Heelas 1986, 240)

There can be no book of instructions for the interpretation of emotion in the past. Obviously the understanding of emotion and experience, as all social archaeology, must make use of contextual information and work within the constraints of the material available (Pinch 1995). Methodologies must be contextually relevant, but the difficulty of developing interpretative strategies should not make us despondent. An understanding that a consideration of experience is important is the first step towards trying to find places to look and ways of interpreting evidence. Who would have thought twenty years ago that such intangibles as power and gender in the prehistoric past would be common subjects for archaeological analysis? Particularly when we are considering, as we frequently are, the material responses to death, to neglect the emotional importance of experience and action in the past produces at best a very partial and highly intellectualized interpretation of archaeological material.

\section{Death and dying in Victorian Britain}

In order to examine the significance of the First World War in British mourning practices, it will be necessary to review the changes which occurred in the decades around the end of the nineteenth century and the beginning of the twentieth. There is a plethora of popular literature about death and mourning in the Victorian period, though rather less scholarly work in the area. Academic discussion of responses to death in the twentieth century is complicated by the moral and social values with which commentators invest modern practices. The putative inability of twentieth-century westerners to face death and deal with it honestly has been the subject of numerous works, notably Philippe Ariès' The Hour of our Death (1977), and Geoffrey Gorer's Death, Grief and Mourning in Contemporary Britain (1965), and the satires of Evelyn Waugh (1948) and Jessica Mitford (1963). The general trend has been to contrast the nineteenth century with the twentieth, indicating a dislocation between the two centuries, and taking the opportunity for the author to champion one over the other. Cannadine $(1981,191)$ for example, challenges the traditional view, and asserts that in contrast with the authenticity of the twentieth century, the nineteenth was a bonanza of commercial exploitation'. Even Cannadine, however, accepts an evaluative contest between these two traditions.

The consensus is that in the nineteenth century we were more in touch with death. We expected it, celebrated it, practised rituals which expressed our solidarity and had a therapeutic function. Mourning is usually understood as a traditional ritual, a badge of tribal identity, conformity to established convention. It had the aim of giving the comfort of secure ritual to those who had suffered bereavement, trammelling emotion into recognized channels of expression, so that the bereaved could gain relief from their pain. This is the view of, for example, Geoffrey Gorer (1965) and Philippe Ariès (1981). By contrast, runs the argument, in the twentieth century, we resist and deny death; it has replaced sex as the major taboo of our age. In consequence, we are denied the therapeutic advantages of ritualistic mourning and the comforts of a belief in an afterlife. Changes in material culture of death - such as the standardization of memorials, and the decline in the importance of cemeteries - are symptomatic of our lack of concern about death and bereavement, in contrast to elaborate Victorian practices.

I have several problems with this kind of approach. The first concerns its empirical truth. As Simpson (1979) says in the preface to his bibliography Dying, Death and Grief, 'Death is a very badly kept secret; such an unmentionable and taboo subject that there are over 750 books now in print asserting that we are ignoring the subject.' The 1987 edition of the bibliography included more than 1700 books. The second point is that that the necessity of making a moral or amateur-psychological judgement on the relative merits of nineteenth- and twentieth-century ways of dealing with death generally precludes any scholarly inquiry into how and why attitudes and practices changed (Cannadine 1981). The third is a distrust of a nostalgia-led view of nineteenth-century practices which interprets Victorian mourning as traditional, formulaic expressions of grief and group solidarity. This view derives excessively from a late twentieth-century standpoint. Victorian mourning practices are traditional to our past, not to the Victorians. ${ }^{3}$ Because our present response to bereavement is to try to lessen the pain, to 'get over' the worst of the grief, it does not follow that the bereaved in the nineteenth century had similar priorities. The primary function of mourning was not 
consolatory, but expressive. What is neglected in the study of the Victorian rite of death was its ability to make an impression, to express something personal: grand rather than cosy, individualized rather than conventional. It is important to remember that what we consider to be 'traditional' Victorian mourning practices were at their flamboyant peak for only about twenty years or so, in the third quarter of the nineteenth century. Moreover, that period was marked by constant innovation in the material culture of mourning. It was not the traditional but the radical, not convention but dislocation which they emphasized.

In the mid nineteenth century at least, the use of mourning was not formulaic. Custom decreed that mourning clothes should be worn for the funeral itself, and for a short time afterwards, but the expansion of funerary paraphernalia was a nineteenth-century invention. Mourning spread beyond the person of the bereaved, to include the house, which could have black curtains, black crockery, note paper, vases, washing bowls - almost everything (Morley 1971; Curl 1972). ${ }^{4}$ The use of all this stuff must have made a dramatic impression. A bereaved person would be able to express, through the metaphor of their material culture, a striking dislocation from a world of colour and light to a dark and monochromatic one, which figured outwardly an inner desolation.

A second line of explanation of nineteenth-century funerary practice centres on the negotiation of relationships of power. According to this understanding the funerary monument relates above all to the power and social position of the deceased and the groups to which they belonged (for example, gender, class, lineage, ethnic or cultural groups) (e.g. McGuire 1988; Richardson 1988; Parker Pearson 1982). The problem with these kinds of approaches is that they can be insufficiently historical (although see Wurst 1991). The specific form of material culture and its particular context is frequently not considered. Why are status relationships worked through in this way in the nineteenth century rather than in the eighteenth or the twentieth? Why do Victorian memorials take the form they do? Above all, what is the particular significance of the funerary context? Death and bereavement are very particular and very meaningful parts of human experience. This consideration is frequently neglected in interpretations of mortuary archaeology which make the manipulation of power the 'bottom-line' of archaeological explanation (e.g. Barrett 1987; 1988; Thomas 1991). The context of burial makes strikingly evident the insufficiencies of power-centred explanatory schemes, which necessarily brush over the fact that they are concerned with responses to death. The use of social theory, particularly the work of Anthony Giddens (e.g. 1984), in archaeology has enabled more nuanced understandings of the way in which societies are created and recreated through an everyday experience which is articulated in material culture, amongst other things. The use of this kind of social theory to consider the archaeology of death may, however, mask strong human emotions by emphasising 'routine' practices. Several recent approaches to the archaeology of death have underplayed the exceptional and discordant nature of death, by stressing the ritual aspects of funerary behaviour, the transference of knowledge and the reproduction of power (e.g. Mizoguchi 1992; 1993; Barrett 1994). As Renato Rosaldo has said,

Putting the accent on the routine aspects of ritual conveniently conceals the agony of such unexpected early deaths as parents losing a grown child or a mother dying in childbirth. Concealed in such descriptions are the agonies of the survivors who muddle through shifting, powerful emotional states. (Rosaldo 1986, 186)

This criticism is directly relevant to the study of recent, Western burial practices. Michael Parker Pearson understood nineteenth-century burial as being about social competition, where 'the dead may be used as one of many modes of social advertisement between competing groups' (Parker Pearson $1982,112)$. By contrast, in the twentieth century class distinctions are masked at burial. In both cases, the primary way of understanding burial is by its role in reproducing ideologies of power. Again, the problem here is with explaining the significance of the context of status negotiation: in this case the commemoration of the dead. The way to address this question must be to consider historically the particular ways in which death and burial were understood in the past. Such considerations necessarily involve emotions such as grief and fear, metaphorical and figurative understandings of death, as well as the position of the living bereaved in their society and it is important to point out that the social motivations of the bereaved are more complex and less cynical than simply the pursuit of status or class interests.

In fact our underlying feelings about death have probably not undergone any dramatic transformation since about 1800 , and what appears as such a radical change around the turn of the last century is more a crisis of expression than a fundamental change 
in attitude. In the period from the late eighteenth century to the present, bereavement has been characterized by a strong emotional response. This relates to the growth in the West of what Stone (1977) calls 'affective individualism' - an understanding in which bonds of sympathetic emotion link atomized individuals. Marriage and familial relationships in life have been characterized by romantic or sentimental love, and at death the feelings of grief and loss experienced are profound and painful. As mentioned above, the mourning practices of the nineteenth century can be seen as indicative of a desire by the bereaved to express a unique and personal loss, to distinguish your bereavement, and thus your relationship, from others.

\section{The First World War}

In the latter part of the nineteenth century, many practices which had originated as deeply personal expressions of grief became conventionalized. The use of elaborate mourning started to be seen as compulsory, and consequently powerless to express a grief which felt personal, unique and profound. Just as we commonly complain that 'all the words have been used before' when we try to express deep feelings such as love, grief or gratitude, in material culture, as in language, forms of expression can and do become clichéed. Because other people have used them, the expressions available to us seem insufficiently personal and powerful. New ways of articulating the relationship between the living and the dead had to be found, and these new trends moved commemorative practice away from the public and ostentatious expression of grief towards the private, personal and simple. The simplicity and authenticity of nature was invoked. (The desire for authenticity and simplicity was evident not only in mortuary practices, but in many areas of cultural life in the later nineteenth century). The First World War played a large part in the crystallization of the changes in responses to death, but many of the changes imputed to the war had actually started before the end of the nineteenth century. Burial reform - the genesis of the garden cemetery, the 'earth-to-earth' funeral which emphasized a bio-degradable coffin and natural coffin furniture such as beds of moss and pillows of herbs, and the legalization of cremation (Haden 1975, in Curl 1980, 199) - are often associated with the First World War. In fact the reforms began considerably earlier, in the 1870 s and 1880 s. But the particular circumstances of World War I accentuated the insufficiency of nineteenth-century approaches and brought their own specific difficulties for the bereaved.

First there was the lack of physical remains. The army decided not to ship bodies back to Britain for burial, nor even, until after the war, were families allowed to transport the bodies of their kin home, and then only if the family could afford the transport (Mosse 1979). Instead, the fallen were buried near their places of death. For many, there was no known grave at all - the body literally blown to pieces, decaying where it fell or lying unidentified in a shallow battlefield grave. Therefore, except for those whose sons, brothers and husbands had died in convalescence, the location of the remains was not accessible as a focus for mourning and remembrance.

Secondly, the scale of the tragedy was unprecedented. A whole generation was reduced by almost a third. Bereavement frequently did not come singly: many people lost several of their friends and family. Moreover, those left behind were aware not only of their own losses, but the repetition of grief and pain through the families of friends and acquaintances. The scale of killing in the First World War is well-known, but it is worth rehearsing a few figures. Altogether about three quarters of a million British men died as a direct result of the war, and about twice that number were disabled. This was utterly unprecedented in the history of war. It has been pointed out that the loss of 20,000 men on the first day of the battle of the Somme exceeded the sum of all British deaths in the Boer War (Cannadine 1981, 197). Of the men aged 20-24 at the outbreak of war, over 30 per cent were killed, and of those aged 13-19, 28 per cent were to lose their lives (Winter $1977,450)$. This scale of killing meant that nearly every household in the country suffered at least one loss, and we cannot doubt that the First World War represented horror and grief for almost every family and every community in Europe (Winter 1995, 2).

Third, there is the particular horror of the nature of the First World War deaths. By the early years of the twentieth century, death and dying happened increasingly in hospitals, cleanly, painlessly and at an advanced age. Death in war, death at a young age was less and less anticipated. The First World War reversed this pattern. It was the young and healthy who were dying in massive numbers. Moreover, they were dying painfully, grotesquely and, crucially, unexpectedly. Before the war, nobody had thought it possible that so many might die. The risk of death in battle was slight and glorious. Parents had not expected that their sons would come to any real harm. War was 'an extension of Games' (Cannadine 1981, 195). 
The bereaved of the war were ill-equipped to respond to their particular kind of loss. Nineteenthcentury practices were obviously insufficient. The experience of those who waited and were left widowed or orphaned by the War was more traumatic than some of the literature which concentrates predominantly on the experience of those at the front might suggest. Mosse, for example, describes tours to the cemeteries of Flanders in the years after the First World War as part of a 'trivialization' of war which was 'indulged in' by those who stayed at home during the war and by those too young to have fought (Mosse 1990, 7). However, those are the people, presumably, whose husbands, sons and fathers were killed in the war.

War deaths could not be treated as though they were normal kinds of death; the dead were not just any dead, to be commemorated as other dead were commemorated. New responses were demanded. These responses took place at three levels: the national, the local and the personal. At a national level, the war dead were memorialized in many ways, including an annual Day of Remembrance, and the institution of two minutes' silence throughout the nation. Locally, and materially, the graves of the war dead were marked by special military gravestones, and their deaths commemorated by memorials in their communities. Personal responses involved an enduring relationship with individual dead, through the curation of souvenirs and photographs and spiritualist contact. I want to discuss briefly each of these responses, focusing particularly on those of the local community: the war memorial. The examples of commemoration of the war dead will mostly be taken from personal observations made in the Orkney islands. In terms of the scale of loss, the experience of Orcadians was typical of Britain in the First World War. However, Orkney differed from much of Britain at this time in its economic and demographic circumstances. The Orcadian economy was based on fishing and agriculture and was primarily a rural society. The population of Orkney had undergone a serious decline in the four decades leading up to the First World War, owing mostly to emigration overseas (Barclay 1965). Unlike the cities of the south, the population of Orkney was religiously and ethnically very homogeneous - English-speaking and Protestant.

\section{Military cemeteries}

British military cemeteries are mostly close to the battle sites themselves, so that the largest of them are in France and Flanders. There are some military cemeteries from this period in Britain, however, one of which is at Lyness on Scapa Flow in Orkney. Scapa Flow was the base of the Grand Fleet for much of the War, and the cemetery site at Lyness was purchased by the Admiralty during the war. It contains 458 burials of First World War dead - mostly men of the Royal Navy or the Royal Marines, although some members of other forces, including overseas ones, are also buried there (Imperial War Graves Commission 1931).

All war graves for which the British Services were responsible are marked with headstones of the same size, shape and material. There are minor differences between those for the First and those for the Second World War. A standard military gravestone is made from grey granite, polished on the front, but not on the sides or back (Fig. 1). On First World War stones the first line of the inscription is the service number of the deceased, followed by his rank, name, regiment or ship, date of death and age. The central part of the stone is occupied by a regimental badge and a cross or appropriate religious symbol. (In the Lyness cemetery there are other symbols on some of the Second World War graves, such as a Star of David, a Crescent and a yin-yang symbol.) At the bottom of the stone an epitaph chosen by the family might appear. This concession to individualization was only permitted later in the War after protests from families. Second World War stones generally have the same arrangement, except that the service number no longer necessarily appears. No distinction between ranks is made in the form of the stone, or in its position in the cemetery. All war dead are accorded equal honour in the military cemeteries.

The organization of the graves of servicemen in the military graveyard at Lyness is remarkably similar to the organization of a military drill. The graves are arranged in straight, parallel rows, each grave the same distance from its neighbour (Fig. 2). They all look the same, and little individualization is permitted on the stone itself. Only the personal details and the epitaph distinguish the graves from one another, and even they are strictly controlled in the amount of space and the position on the stone which they occupy. The few German graves in the Lyness cemetery have been allocated a separate area well away from the graves of Allied servicemen, so that political divisions in life are also spatially maintained in death. The message is that even death cannot break the bond between the man and his Service. The greatest amount of space on the stone is allocated to the depiction of the Regimental badge. No wives, parents, children or other individuals are 


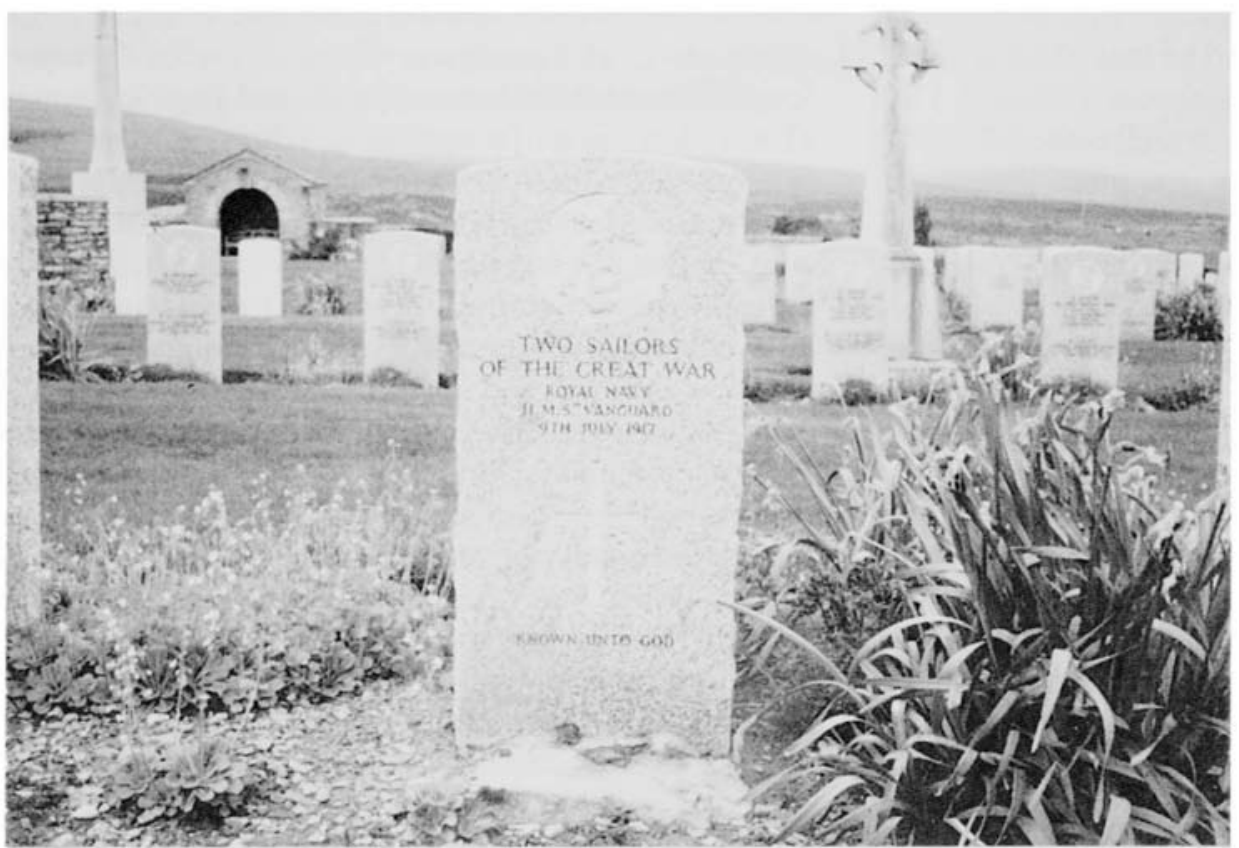

Figure 1. Standard military gravestone from Lyness cemetery, Orkney.

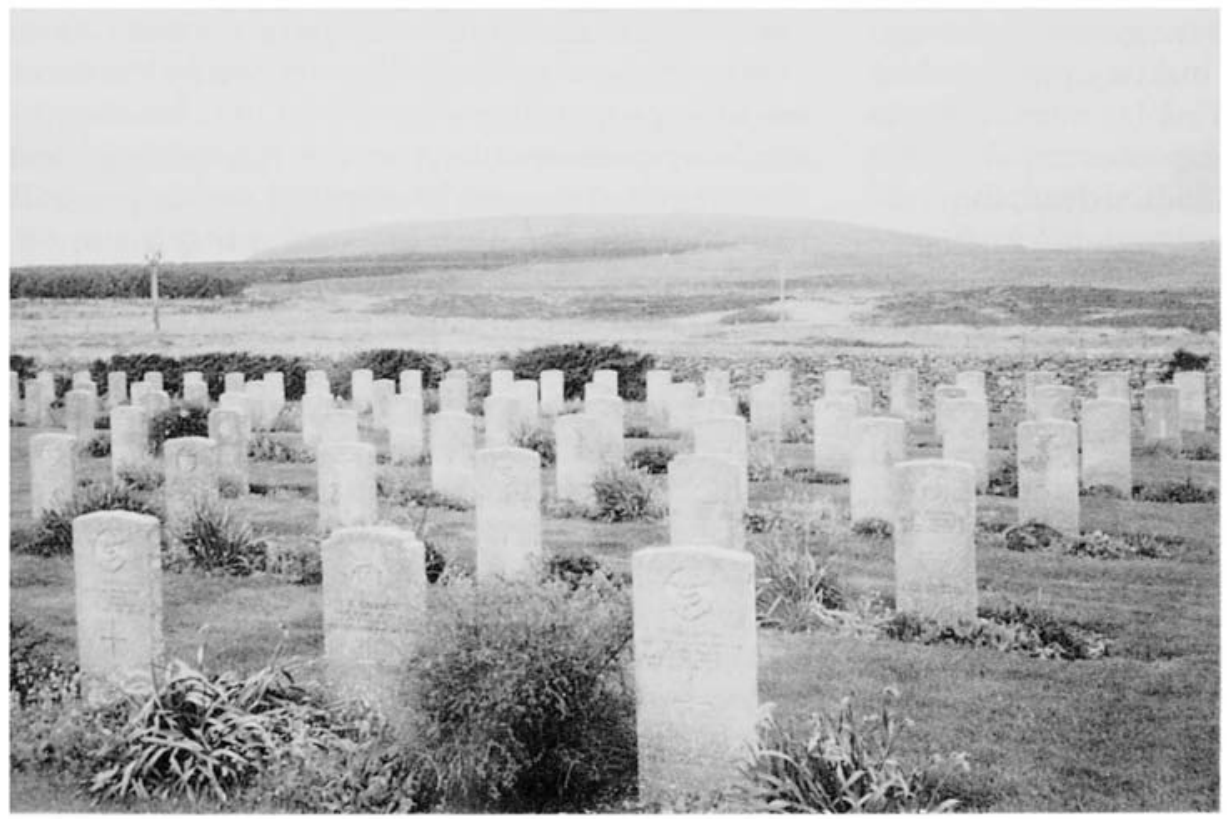

Figure 2. Part of Lyness military cemetery, Orkney.

named on the stone. The only allegiance recorded is to the group (regiment or ship). The individual is commemorated as a serviceman - other roles, other relationships, individualizing details are not given. The military stones, and the military cemeteries, are conspicuously different to the grave stones and cemeteries of the civilian dead. Mosse $(1990,92)$ suggests that this distinction maintains that the death of the soldier is of national, public importance, as compared to the narrowly local, private significance of the civilian death. The standardization of military monuments is also, of course, affected by the need of the authorities to produce large numbers of memorials expediently and economically. But for the families of the deceased, the official commemoration was unsatisfactory. In the majority of cases, of course, the gravestone was not accessible, being in France, even if the remains of the dead soldier could be identified, which was frequently not the case. But even in those circumstances where an individual was buried in a local graveyard, the military stone was often accompanied by inclusion on a family memorial

For example, at St Mary's in Rousay is the Services gravestone of Private $H$. Reid of the Seaforth Highlanders who died in 1917 at the age of 23. (Although most casualties of the war are buried in military graveyards, in cases such as Private Reid's, where he died convalescing in Orkney, the burial took place in a local graveyard.) Immediately adjacent to it is the stone erected by Private Reid's father in memory of his mother Harriet Logie, who died in 1894. Harry Reid's name has also been added to this. family memorial stone, although it does not mark the place of interment. The family gravestone allows Private $\mathrm{H}$. Reid a first name and a family relationship. The names of servicemen who were buried away from their home 
parishes are commonly inscribed onto family memorials in the parish graveyard. This private commemoration remembers the deceased not only as a soldier, but as a member of a family and a local community.

\section{War memorials}

Because the bodies of the war dead were generally buried in large cemeteries at the site of the battle, and only the graves of those few who happened to die near to home were easily accessible to bereaved relatives, it was felt necessary to mark a location which could act as a focus for local commemoration. Family gravestones frequently appended the name of a soldier, and memorialized the individual through their personal and familial relationships, as in the case of the Reids' gravestone in Rousay, but the First World War also produced a class of monuments which combined local commemoration with the treatment of the war dead as a special category: the war memorial.

The national war memorial - the Cenotaph in London - was originally constructed in plasterboard as a temporary structure for the Victory Parade of 1919. Within 11 days of the Parade the Government had been forced by public pressure to make the Cenotaph permanent.

The construction of the Cenotaph in London was phenomenally popular (Cannadine 1981). The permanent cenotaph was unveiled as part of the Armistice Day celebrations of 1920 . Also on that day the body of an unknown soldier brought from Flanders was given a state funeral in Westminster $\mathrm{Ab}$ bey. Within a week of its unveiling ceremony, about a million people had visited the Cenotaph and the grave of the unknown soldier to pray, mourn, pay tributes and lay flowers.

The memory of the British dead of the First World War is most strikingly preserved, however, in the hundreds of thousands of war memorials throughout Britain. All over the country, in the years following the end of the war, communities were building their own war memorials to commemorate their own dead. Cities, towns, villages and parishes; schools, churches, societies and factories dedicated memorials throughout the ensuing decade. Every Orcadian parish built a war memorial in the years following 1918. These provided a local focus, not only for the rituals of Armistice Day, but also for mourning, when the actual bodies of the dead were buried in France, frequently unidentified. Some analytical literature exists about the construction and form of European War memorials, although most of it focuses on the memorials designed to be situated either in the cemeteries of Flanders, or in capital cities as national memorials (such as Whittick 1946; Curl 1980; Mosse 1979; 1990). Despite the recent completion of a register of local memorials in Britain (by Catherine Moriarty of the Imperial War Museum), studies of local community memorials are uncommon (although see Gregory 1993). This focus on major state memorials situates First World War memorials rather differently, as part of a national, or even a nationalist project. Local war memorials are different in style, origin and meaning, and were part of an essentially local and community expression. The other distortion produced by literature which focuses on the major monument alone is the impression given that the erection of collective commemorative monuments was primarily an invention of the First World War. In Orkney, for example, the erection of the Covenanters' memorials in Kirkwall and at Moull Head, financed from public funds, preceded the First World War by some time. The erection of communal memorials to commemorate worthy dead was a practice with which Orcadians were already acquainted, and not a totally new form of expression.

The Kirkwall war memorial, which is in the form of a gate to the graveyard, is surmounted by an angel holding aloft a torch (Fig. 3). The names of the fallen are inscribed on the sides of the gate. In Pierowall, on the island of Westray, the memorial is a five metre granite obelisk, inscribed with the names of the dead (Fig. 4). The Pierowall memorial is not inside the kirkyard, but across the road and about 75 metres north of the cemetery. It is set back from the road, enclosed by a fence, with a path and some steps leading up to it. The Papa Westray memorial is also positioned by the road, at the highest point of the central part of the island. Both memorials have views over fields to the sea. The fence surrounding the memorial has several functions. It protects the monument from animals, it demonstrates to onlookers that the monument has a certain protected status, and it serves to mark out a privileged area (even, as Mosse $(1990,100)$ suggests, a sacred space) around it, which was important particularly during the ceremonies which took place there. All war memorials are taller than other grave memorials. This height is sometimes exaggerated by situating the memorial in a position of high natural elevation, such as on Papa Westray. Thus the memorials dominate the surrounding area, and necessitate the viewer looking up at them. The memorials themselves are traditionalist, 


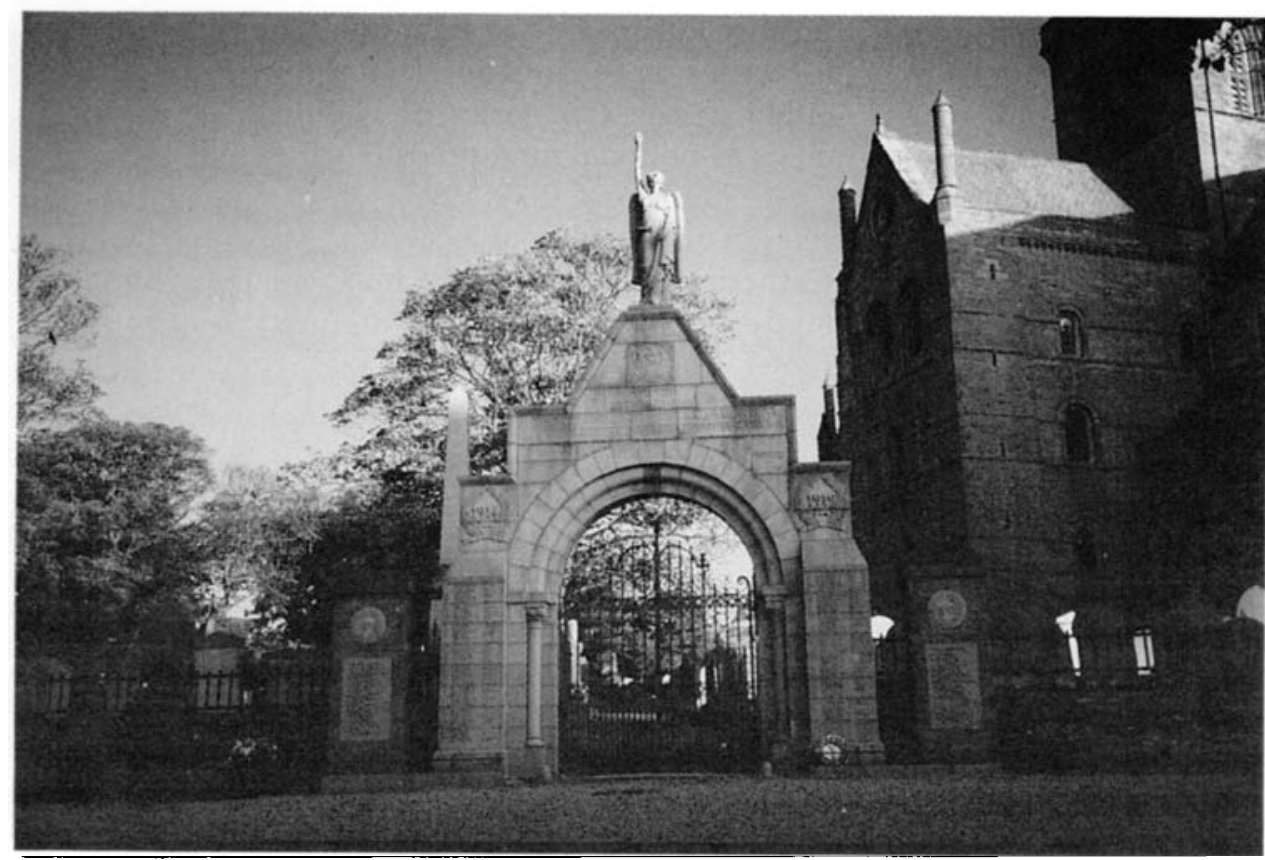

Figure 3. The war memorial at Kirkwall, Orkney, is in the form of a gate to St Magnus Cathedral cemetery.

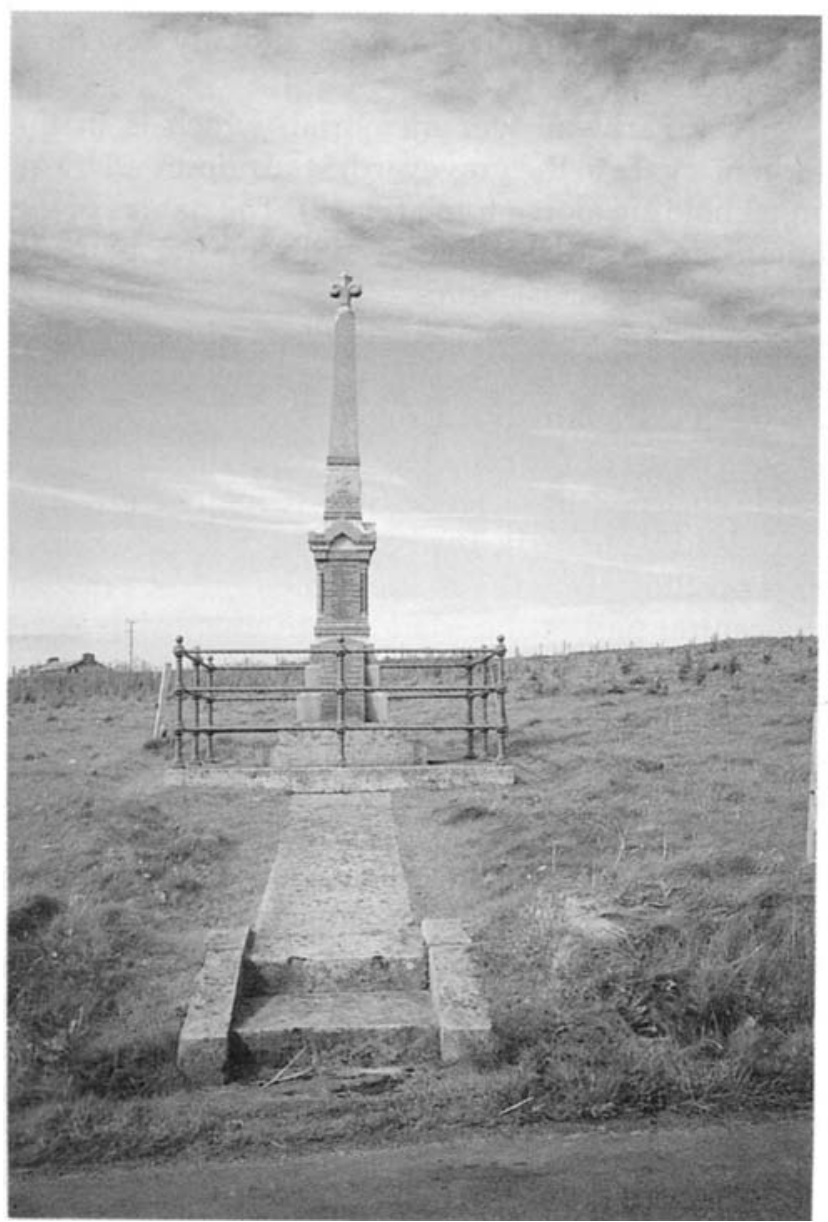

rather than modernist in design ( $c f$. Winter 1995) and, in distinction to the massive national memorials, are frequently figurative, incorporating weary soldiers, or benevolent angels (such as at Kirkwall).

\section{The patriotic and the personal}

What I particularly want to stress in discussing all these responses is the degree to which personal emotions such as love and grief were involved in these forms of commemoration. Many of those who have written about war memorials stress their role in the creation and reproduction of patriotic or nationalistic feeling, as part of a political landscape (e.g. Mosse 1979; 1990; Parker Pearson 1982; Rowlands 1993). For example, Mosse (1990) places the erection of the war memorial in the context of the creation of a myth of War experience, which would mask the reality of war, transfigure the unacceptable, and not only console the bereaved, but also justify the nation. He contends that 'those concerned with the image and the continuing appeal of the nation worked at constructing a myth which would draw the sting from death in war'. This view is problematic because of the vagueness as to who 'those concerned with the image and the continuing appeal of the nation' actually are. Although perhaps some of the larger national monuments to the dead might have been erected at government instigation (although the London Cenotaph was made permanent by public, rather than political demand), most local memorials were commissioned by the local community in commemoration of their personal dead, and had no particular interest in maintaining a myth of nation. The putative dupes of national myth in Mosse's argument are the very people with whom the monuments originated, and by whom they were chosen. This is not to say that nationalist sentiment had no place in the process of mourning and in making sense of personal loss, but that the reference to nationalist ideology was, in the case of community

Figure 4. The war memorial at Pierowall, Westray. 
war memorials, made from personal, local choice, rather than government sponsorship. Nor does Parker Pearson's interpretation that war memorials functioned to legitimate 'Nationalism as an ideological means of control' $(1982,111)$ take into account that war memorials were initiatives which came from the people rather than the politicians. Whatever the subsequent appropriation of the apparatus of commemoration has been in the years since the Second World War, at the time of their innovation they were demanded, paid-for, commissioned and located by the bereaved public. Both public and personal, local and national forms of commemoration were supported by, rather than imposed upon, the people of Britain.

Most local memorials were commissioned by the local community in commemoration of their personal dead. The majority of British war memorials appear to have a local rather than a national focus. The community, rather than the nation, is reconstituted in them. The actual construction of the memorial was in itself a way of recreating the bonds of community after the war. The names listed on the memorials tell not only who were the fallen, but also the names of the families who had been bereaved (Winter 1995, 95). The Pierowall memorial even gives the names of the houses from which the dead came, bringing the dead back into the heart of their community. Relationships within and between families and communities which had been disrupted during the war were to some extent re-established in the community activity of commissioning, planning and taking decisions about a memorial.

As Parker Pearson (1982), Mosse (1990) and others have indicated, the memorial, like the war cemetery, subsumes individual difference in the unification of military status and the act of death. To group together the fallen stresses the homogeneity of war experience (Mosse 1979, 7). To what extent this is for what Rowlands $(1993,145)$ calls 'the resolution of the religious force of nationalism within the secularised ideal of remembering those sacrificed for the nation' is arguable. Whilst the idea of national allegiance is undoubtedly strong, the memorials are not so prescriptive as is implied in much of the literature. They emphasize the shared experience of bereavement, and it was sensitivity to the needs of the bereaved which characterized these monuments at their time of construction.

When we turn to look at the memorials themselves, their mood is neither glorious nor nationalistic. The faces of soldiers depicted on war memorials express fatigue and sadness, not aggression or glory.
The sadness of war is not part of political expression, but of the experience of those who had seen death or suffered bereavement. It is their experience which is commemorated.

The war memorials are in traditionalist rather than modernist styles, and frequently invoke distant antiquity. Winter suggests that the strength of the 'traditional' monumental style, entailing 'everything the modernists rejected: romanticism, old values, sentimentality ... clichés about duty, masculinity, honour [lay in] the power of traditional languages, rituals, and forms to mediate bereavement' (Winter 1995, 115). Both the Westray and Papa Westray memorials from Orkney are in the form of obelisks. To some extent this reflects the artistic conservatism of a rural population, but it also gives to the monuments an essential form which transcends the historical occasion of their institution (Rowlands 1993, 145). It is worth noting what the memorials do not represent. They do not depict acts of killing and only rarely figure the dead or dying. Their mood is solemn, but not horrific and not despairing. Structurally they do not involve the absolute horizontality of hopelessness (Winter 1995, 93). Instead they are upright architectural forms such as obelisks or pillars. Figurative memorials do not show soldiers lying down. When, rarely, a dead or dying soldier is figured, he is usually being lifted by an angel, an attitude which invokes our understanding of Christian eschatology, and we recognize it to mean resurrection.

The invocation of metaphors of resurrection and transfiguration are central concerns of the war memorial, which had a consolatory as well as an expressive role. This idea of transcendence is approached through traditional and familiar metaphors. Mosse also notes the popularity of symbols of nature and natural renewal in British war memorials. He argues that the association of war dead with the pastoral (as, for example, in the use of poppies in commemorative ritual) transfigures the horror of war death by representing it as natural and eternal. The flowers suggest resurrection of the immutable nation (1990, $89-90,110-11)$. The gloss of nationalism is not necessary to understand the popularity of the pastoral symbolism of the poppy. It does not represent the transfiguration of the experience of death, but the transfiguration of the dead for the bereaved.

Whether invoked singly or in association with one another, what all these registers - the antique, the natural and the Christian - bring to the context of remembering is an idea of timelessness, of an order beyond the day-to-day affairs of individuals, 
nations and the political world. Bauman (1992) has discussed the 'existential anxiety' which is provoked by the confrontation with death. Treherne $(1994,35$ 6 , following Vernant 1991) has described the response of Homeric Greeks to the horror of physical decay. He suggests that 'the culmination of a beautiful death in funerary rites fixes a place for the deceased both in the landscape and in the minds of others and as such is one way to obviate the horror and anonymity of death's threshold'. The slain of the Great War can by no means be said to have had a beautiful death, and this makes the transfiguration of the physical horror into something which could be inscribed in the memory of the living (cf. Thomas 1991) more urgent. This was necessary not only to alleviate the existential anxiety of the survivors, but also to secure the memory of the dead. In Britain, flowers are a traditional symbol of lamentation. The flower is characterized by beauty and by transience, but also brings with it the suggestion of regeneration, which is why it had been a popular metaphor for the dead (and not only the war dead) for many centuries in Britain, used on memorials since at least the Reformation.

References to nation or to Christian religion provided a way of seeing death in general, and deaths of the First World War in particular, which made sense to the bereaved of senseless slaughter. Indirectly, such an understanding strengthened nationalistic feeling. It was not adopted for the sake of 'the nation', or in order to manipulate its citizens, however, but for the personal meaning it had to individuals. This way of seeing effectively transcends individual death, as Bauman explains, by emphasizing the immortality of the group $(1992,26-7)$ - what Borkenau $(1965,48)$ has called the transference of immortality from the individual to the community', the community in this case being either the nation or the Christian people. Davies (1993) points out the Christian redemptive theme of many memorial inscriptions (e.g. 'They died that we might live' [Kilmartin, Argyllshire] or 'Greater love hath no man than this: that he lay down his life for his friends' [ubiquitous]). Bauman $(1992,27)$ goes on to say that such 'tribal/totalitarian ideologies demand sacrifice of life' [his italics]. The popular uptake of this theme in a Britain ravaged by war seems, however, to have been descriptive rather than prescriptive. Before the war, glorification of death in battle for nationalistic reasons was ideologically very strong, but in the years after 1918 the requirement to die for the nation was not present to the same degree. The idea of transcendence was important for the understanding it provided retrospectively, not primarily for the reproduction of nationalist feeling. No tribal ideology prepared the ground for the next major conflict of this century. The Second World War was entered into in a very different spirit from the First. There was trepidation and sobriety, and no rush of ardent young men 'out for death or glory' (Cannadine 1981, 232).

\section{Much beloved and sadly missed}

Not all memorials to the dead were public. The other development in responses to death at the time of the First World War relates to the removal of the place of commemoration from the cemetery and into the home and the mind of the bereaved. Many of these changes in commemorative practice had started well before 1914, so it cannot be maintained that the First World War itself produced the major changes. Certain rituals of commemoration, however, such as the two-minute silence on Remembrance Day, were developed in response to the war (Cannadine 1981, 222). As I mentioned earlier, changes in the manner of remembering seemed to have more to do with a crisis of expression than a fundamental change in attitude. In the twentieth century, as in the nineteenth, the bereaved of a highly individualistic society do not seek to lose themselves and their grief in a mire of traditional ritual, but to express a very deep and personal emotion. When modes of expressing that emotion become institutionalized, alternative voices must be found. In the twentieth century, such alternatives were sought in the object of commemoration (the gravestone or memorial), the style of mourning (the two-minute silence, the decline of formal mourning wear), and perhaps above all in the venue of remembering. The opening of many new out-of-town cemeteries and crematoria occurred at a time, in the early part of this century, when the cemetery was becoming less important in the remembrance of the dead. It was part of a trend towards the removal of the place of remembering from the place of the remains. People were going less frequently to the cemetery to mourn their dead. As the grave monument became less important in the commemoration of the dead, the location of mourning moved increasingly to the private home. Geoffrey Gorer has noted an increase in the 'mummification' of the home - the transformation of rooms in the house into shrines to the deceased by preserving them as they were when the person died (Gorer 1965). More common than the preservation of a whole room is the use of photographs of the deceased as a way of remembering them, and unlike many other European countries, in Britain photographs of the 
dead are generally kept in the home rather than at the cemetery. From the later part of the last century, photographs became more easily available, and increasingly replaced other forms of remembering (journals and keepsakes, as well as memorials). The private space of the home replaced the public space of the cemetery as the place of memory. I do not know anywhere where this is expressed so clearly as in Wilfrid Owen's sonnet for the dead of the First World War, figuring the accoutrements of death and funeral in domestic, internalized terms:

\begin{abstract}
What candles may be held to speed them all? Not in the hands of boys, but in their eyes Shall shine the holy glimmers of good-byes. The pallor of girls' brows shall be their pall; Their flowers the tenderness of patient minds, And each slow dusk a drawing down of blinds. (Owen 1946 [1920], 80)
\end{abstract}

When there were no remains, or the body was buried in France or Flanders, the remembrance of the dead was relocated not only to the war memorial, as discussed above, but also to the private home, and the personal memory. One other response to death which is closely linked to the trends of relocation of mourning, and de-emphasizing the physical remains, was the development, particularly in the period following the First World War, of spiritualism. At the outbreak of the war, interest in spiritualism was more or less confined to a small group of academic men, and a tiny movement of table-tilting cranks trying to find evidence for life after death (Cannadine 1981, 228). As a result of the war, however, the appeal of spiritualism changed radically. Women as well as men became involved in the movement, not so much as an academic endeavour to explore the fate of the soul after death as an attempt to communicate with family and friends they had lost. The spiritualists answered a need and were suddenly relevant for those whose relatives had been snatched away; people wanted those deaths to be mitigated by the knowledge that the dead were in some way present, had not altogether ceased. In fact, although the huge popularity of spiritualism was new at the end of the war, a concern with articulating close and personal relationships between the living and the dead was strong in the nineteenth century. The immediate postReformation understanding of the relationship between the living and the dead centred on the preparation of the living to follow the dead to judgement and then to glory, or to everlasting damnation. From the late eighteenth century, by contrast, the living bereaved related to their dead as individuals, and the relationship after death corresponded to the kind of relationship in life. Essentially, the association was individual and emotional, and the relationship was not between past and future states, but a synchronic relationship between a living and a dead person (Tarlow 1995). This is generally evident through the popularity of metaphors of sleep which effectively 'presence' the dead; and in the promotion of the idea of an eventual reunion between the living and the dead (Cecil 1991). Neither the metaphor of sleep nor the idea of a Heavenly reunion is widely present before the end of the eighteenth century. Both of these consolatory ideas continue to be popular to the present day, but in the immediate post-war period the spiritualist movement provided a very direct way of mediating the personal relationship between individuals. In the years between the wars it was estimated that there were more than 2000 local spiritualist societies affiliated to the Spiritualist National Union, and probably more than quarter of a million committed members (Cannadine 1981, 229).

It may appear that there is a contradiction between the emphasis on community and shared emotion, evidenced in the war memorial and the two minute silence, and the personal, meditative forms of mourning suggested by photographs and keepsakes. Although this is alien to our present experiences of bereavement, however, there is nothing inherently contradictory about sharing the experience of personal grief. This is perhaps best exemplified in the institution of the two-minute silence.

The rituals of Armistice Day, despite their grand and national nature, originated by popular demand. As Cannadine $(1981,219)$ says

... the Armistice Day ritual, far from being a piece of consensual ceremonial, cynically imposed on a divided and war-weary nation by a cabinet afraid of unrest and revolution, was more a requiem demanded of the politicians by the public. Pace Ariès, this 'cult of the dead' was not so much 'an expression of patriotism' as a display of bereavement. It was not a festival of homage by the citizens of the state, but a tribute by the living to the dead.

The idea of commemorating the dead by a period of silence on the first anniversary of the Armistice was suggested to the Cabinet which, despite, some opposition within parliament, generally supported the proposal. This account, from the Manchester Guardian, 12th November 1919 (quoted in Cannadine 1981, 222), captures some of the intensity of the first twominute silence:

The first stroke of eleven produced a magical ef-

fect. The tram cars glided into stillness, motors 
ceased to cough and fume and stopped dead, and the mighty limbed dray horses hunched back upon their loads and stopped also ... Someone took off his hat, and with a nervous hesitancy the rest of the men bowed their heads also. Here and there an old soldier could be detected slipping unconsciously into the posture of 'attention'. An elderly woman, not far away, wiped her eyes, and the man beside her looked white and stern. Everyone stood very still ... The hush deepened. It had spread over the whole city and become so pronounced as to impress one with a sense of audibility. It was a silence which was almost pain ... And the spirit of memory brooded over it all.

Cannadine $(1981,222)$ points out that the key to the extraordinary success of the silence was that it made public and corporate those unassuageable feelings of grief and sorrow which otherwise must remain forever private and individual'.

The reason for including a description of the two-minute silence in an article ostensibly about material culture is in order to illustrate the role of commemorative practices in making public and shared what is a personal and unique grief. I also want to try to convey this feeling of sadness. In the years after the war, it is neither patriotism nor nationalism which seems to have been the central emotional pivot of commemorative activity, but regret and grief. The public expression of personal grief is as much a preoccupation of the first part of the twentieth century as it was of the nineteenth, although the structures of expression were altered, particularly by the war. Silence, stillness and simplicity owed much of their expressive power to the contrast not only with the noise of battle, but also with the literal and figurative 'noise' of the nineteenth-century funeral.

\section{Coda}

Time passes. The profoundly personal and emotional circumstances which led to the construction of these monuments inevitably change as those that are left grow old, and eventually die. Their particular, unique loss is gradually replaced by the commemoration of a historical event. As we write and rewrite our histories, so the meaning of the memorial has changed. First, there is their appropriation by church and state. As time has passed, the maintenance and rituals of remembrance centred upon the war memorials have come increasingly under the control of politicians, clergy and the armed services. The lay public are spectators rather than participants of ritual, if they are involved at all. Associated with this appropriation is the marginalization of remembrance.
Armistice Day itself is no longer celebrated on the 11 th of November, but on a quiet Sunday morning. The two minute silence is observed by church congregations, scouts and guides, the Royal family and the dwindling membership of the British Legion. For most of us it passes unnoticed. The meaning of Remembrance ritual has altered in part because there has been a loss of emotional intensity, and partly because those involved with its celebration have reglossed it. War memorials and the rituals of Armistice Day are no longer the inventive response to intense and personal grief and loss, and are now more about national history and tradition. Shared understandings of what the losses of the First World War meant have been appropriated and transformed, often to more overtly political purposes. This transformation is dialectically involved with the removal of grief from the public arena and into the private and personal home where it is less accessible to nationalist and political propagandists.

The meaning of war memorials and commemorative ritual has changed over the last fifty years, through reappropriation of the structures of remembering. It is worth pointing out that although transformed, meanings have not been altered utterly. Earlier associations are played upon and reworked through time: so that war memorials still generally refer to solemnity, religion and sacrifice, although the social meanings of those ideas now refer more to the idea of history, nation and tradition than to expressing and understanding a private grief.

Modern Europeans are, in Jon Davies's words, a bellicognisant, if not necessarily a bellicose society (Davies 1993, 116). Our history is marked out by wars: pre-war, inter-war and post-war. We use a metaphor of war to understand personal, class, gender and political relationships. War is part of our socialization (Davies 1993, 116). The war memorials of Europe inscribe this shared history, this identity and this community into the landscapes. They serve as foci for political and personal ritual, dependent on a shared history.

A developing common European culture needs to address the ethnic and political relationships established by wars. In the future, it seems likely that our shared European history will be re-worked with reference to a common 'Euro-Christian' view of war (Davies 1993, 121). Whatever languages we speak, no European could fail to recognize this particular conjunction of signifiers:

$$
\text { 1914-1918 }
$$

The transformation of meanings of war memorials, and of the general archaeology of war, is central to 
the writing of European histories. The controversy surrounding the commemoration of the fiftieth anniversary of the liberation of Auschwitz in January (1995) is a good example of this. Jewish bodies resisted what they saw as attempts by the Polish authorities to appropriate the history of Auschwitz for their own national history. Davies $(1993,124)$ points out the problems of commemorating World War Two in a political climate which emphasizes European cohesion; in particular, that there could be an agreement to forget what happened to Europe's Jews. Being the fiftieth anniversary of the end of the Second World War, 1995 made explicit many of the problems of war commemoration: not only Auschwitz, but also the issue of Japanese participation in commemorative activities, the proper way to mark the civilian deaths which resulted from British aerial bombardment at Dresden and elsewhere and so on.

\section{Conclusions}

We should remember that the commemoration of the dead is a very specific and a very emotional context. In our interpretations of the archaeology of death, the mortuary context is more than incidental. Relationships between the living and the dead must be central to our interpretative practices. Archaeologists have used the construction of war memorials as examples of the use of material culture in the propagation of manipulative ideologies of nationalism or religion. I hope to have shown that the construction of these memorials was more complex and far less cynical than that. In prehistoric archaeology, too, we should consider the specific emotional and expressive aspects of burial and commemoration rather than reducing all practices to their role in the negotiation of power relationships.

Although the variability of emotional behaviour makes archaeologists wary of its interpretation in the past, the social constructivist view of emotion (e.g. Harré 1986) stresses the way in which emotional experiences are created socially. Death is necessarily an emotional experience, but the nature of the emotions associated with it, and responses to those emotions, are culturally constructed. From such a position, material culture can be seen as involved in the structuration of emotion and thus both important and accessible to the archaeologist. For example, the erection of war memorials produced and enabled certain emotional responses. The form and location of the memorial not only reflected the grief of the bereaved, but also shaped the expression and understanding of bereavement in war by establishing spatial and figurative structures of remembering. In later years, the emotional force of the memorial was drawn upon and reworked towards the production of other emotional responses. Older, powerful meanings of the memorial - redemption, community, death - were employed in the creation of new meanings - nationalism, conservatism, religion.

David Cannadine has said that Binyon's line 'At the going down of the sun and in the morning we shall remember them' was, at the time of its composition, more a description than an exhortation. Each generation will have different circumstances of bereavement and different commemorative practices. But our ways of remembering are complex and are motivated at the level of the community and the individual, as well as of the nation and the state.

\section{Notes}

1. That is, not only those returning soldiers who had lost friends and comrades, but also the women, children, elderly and unfit who were not conscripted and did not volunteer for service at the Front.

2. Such ways of thinking have real consequences in the modern world: in these cases respectively the naturalization of war through the creation of histories in which war is seen as inevitable and logical (Carman in press), and the validation of inter-ethnic conflict by reinforcing the notion that ethnicity is an inherent rather than a sociallyconstructed trait.

3. For the purposes of this article I have presented a simplified and schematized view of 'Victorian mourning practice'. I do not intend to suggest that the Victorians constituted an undifferentiated mass. A detailed examination of differences in attitudes and practices according to age, gender, class, social and political position is, however, beyond the scope of this account. (For some discussion of these issues see, for example, Cannon 1986; 1989; Curl 1972; Davey Smith et al. 1992; Mytum 1989; 1990.)

4. The consumption of ostentatious funerary material culture was an extraordinarily widespread part of Victorian culture, taken up across the boundaries of gender, class, religion and locale (Curl 1972).

\section{Acknowledgements}

Many thanks to all those who have read and commented on this paper, in particular J.D. Hill, Ian 
Hodder, Lynn Meskell, Bill Sillar, Paul Treherne and my anonymous referees.

Sarah Tarlow
Department of Archaeology
University of Wales
Lampeter
Dyfed
SA48 $7 E D$

\section{References}

Ariès, P., 1981 [1977]. The Hour of Our Death. Trans. Helen Weaver. London: Penguin Books.

Barclay, R., 1965. The Population of Orkney 1755-1961. Kirkwall: W.R. Macintosh.

Barrett, J., 1987. Contextual archaeology. Antiquity 61, 46873.

Barrett, J., 1988. The living, the dead and the ancestors: late Neolithic and early Bronze Age mortuary practices, in The Archaeology of Context in the Neolithic and Bronze Age: Recent Trends, eds. J. Barrett \& I. Kinnes. Sheffield: Department of Archaeology and Prehistory, University of Sheffield, 30-41.

Barrett, J., 1994. Fragments from Antiquity. Oxford: Blackwell. Bauman, Z., 1992. Mortality, Immortality and Other Life Strategies. Cambridge: Polity Press.

Borkenau, F., 1965. The concept of death, in Death and Identity, ed. R. Fulton. New York (NY): John Wiley \& Sons, 42-55.

Cannadine, D., 1981. War and death, grief and mourning in modern Britain, in Mirrors of Mortality: Studies in the Social History of Death, ed. J. Whaley. London: Europa, 187-242.

Cannon, A., 1986. Socioeconomic Change and Material Culture Diversity: Nineteenth-century Drave Monuments in Rural Cambridgeshire. Unpublished Ph.D. thesis, University of Cambridge.

Cannon, A., 1989. The historical dimension in mortuary expressions of status and sentiment. Current Anthropology $30,437-58$.

Carman, J., in press. Introduction, in Material Harm: Studies in the Archaeology of War and Violence, ed. J. Carman. Glasgow: Cruithne Press.

Cecil, R., 1991. The Masks of Death: Changing Attitudes in the Nineteenth Century. Sussex: Book Guild

Curl, J., 1972. The Victorian Celebration of Death. Newton Abbot: David \& Charles.

Curl, J., 1980. A Celebration of Death: an Introduction to Some of the Buildings, Monuments and Settings of Funerary Architecture in the Western European Tradition. London: Constable.

Davey Smith, G., D. Carroll, S. Rankin \& D. Rowan, 1992. Socioeconomic differentials in mortality: evidence from Glasgow graveyards. British Medical Journal $305,1554-7$
Davies, J., 1993. War memorials, in The Sociology of Death, ed. D. Clark. Oxford: Blackwell, 112-28.

Fritz, J., 1978. Palaeopsychology today: ideational systems and human adaptation in prehistory, in Social Archaeology: Beyond Subsistence and Dating, eds. C. Redman, M. Berman, E. Curtin, W. Langhorne, N. Versaggi \& J. Wanser. New York (NY) \& London: Academic Press, 37-60.

Giddens, A., 1984. The Constitution of Society. Cambridge: Polity Press.

Gledhill, J., B. Bender \& M. Larsen (eds.), 1988. State and Society: the Emergence and Development of Social Hierarchy and Political Centralisation. London: Unwin Hyman.

Gorer, G., 1965. Death, Grief and Mourning in Contemporary Britain. London: Cresset Press.

Gregory, A., 1993. Armistice Day 1919-1946. Unpublished Ph.D. thesis, University of Cambridge.

Harré, R. (ed.), 1986. The Social Construction of Emotions. Oxford: Blackwell.

Heelas, P., 1986. Emotion talk across cultures, in Harré (ed.), 234-66.

Hodder, I., 1986. Reading the Past. Cambridge: Cambridge University Press.

Imperial War Graves Commission, 1931. The War Graves of the British Empire: the Register of the Names of Those who Fell in the Great War and are Buried in Cemeteries and Churchyards in the Counties of Banff, Caithness, Moray, Nairn, Orkney, Ross and Cromarty, Sutherland and Zetland, Scotland. London: Imperial War Graves Commission.

Kristiansen, K., 1984. Ideology and material culture: an archaeological perspective, in Marxist Perspectives in Archaeology, ed. M. Spriggs. Cambridge: Cambridge University Press, 72-100.

Kus, S., 1992. Towards an archaeology of body and soul, in Representations in Archaeology, eds. J.-C. Gardin \& C. Peebles. Bloomington (IN): Indiana University Press, 168-77.

Leventhal, H., 1980. Towards a comprehensive theory of emotion, in Advances in Experimental Social Psychology, vol. 13, ed. L. Berkowitz. London: Academic Press, $149-207$.

Levy, R., 1984. Emotion, knowing and culture, in Culture Theory: Essays on Mind, Self and Emotion, eds. R. Shweder \& R. Levine. Cambridge: Cambridge University Press, 214-37.

McGuire, R., 1988. Dialogues with the dead: ideology and the cemetery, in The Recovery of Meaning: Historical Archaeology in the Eastern United States., eds. M. Leone \& P. Potter. Washington (DC): Smithsonian Institution Press, 435-80.

McGuire, R. \& R. Paynter, 1991. The Archaeology of Inequality. Oxford: Blackwell.

Miller, D. \& C. Tilley, 1984. Ideology, Power and Prehistory. Cambridge: Cambridge University Press.

Miller, D., M. Rowlands \& C. Tilley, 1989. Domination and Resistance. London: Unwin Hyman.

Mitford, J., 1963. The American Way of Death. London: 
Hutchinson.

Mizoguchi, K., 1992. A historiography of a linear barrow cemetery: a structurationist's point of view. Archaeological Review from Cambridge, 11(1), 39-49.

Mizoguchi, K., 1993. Time in the reproduction of mortuary practices. World Archaeology 25(2) (Conceptions of time and ancient society), 223-35.

Morley, J., 1971. Death, Heaven and the Victorians. London: Studio Vista.

Mosse, G., 1979. National cemeteries and national revival: the cult of the fallen soldiers in Germany. Journal of Contemporary History 14(1) (January 1979), 1-20.

Mosse, G., 1990. Fallen Soldiers: Reshaping the Memory of the World Wars. Oxford: Oxford University Press.

Mytum, H., 1989. Public health and private sentiment: the development of cemetery architecture and funerary monuments from the eighteenth century onwards. World Archaeology 21(2), 283-97.

Mytum, H., 1990. A study of Pembrokeshire graveyards: cultural variability in material and language. Bulletin of the C.B.A. Churches Committee 27 (1990), 6-11.

Owen, W., 1946 [1920]. The Poems of Wilfrid Owen. London: Chatto \& Windus.

Parker Pearson, M., 1982. Mortuary practices, society and ideology: an ethnoarchaeological study, in Symbolic and Structural Archaeology, ed. I. Hodder. Cambridge: Cambridge University Press, 99-114.

Pinch, A., 1995. Emotion and history: a review article. Comparative Studies in Society and History 37(1), 100-109.

Richardson, R., 1988. Death, Dissection and the Destitute. London: Routledge \& Kegan Paul.

Rosaldo, R., 1986. Grief and a headhunter's rage: on the cultural force of emotions, in Text, Play and Story: the Construction and Reconstruction of Self and Society, ed. E. Bruner. Washington (DC): American Ethnological Society, 178-95.

Rowlands, M., 1993. The role of memory in the transmis- sion of culture. World Archaeology 25(2), 141-51.

Shanks, M. \& C. Tilley, 1987a. Social Theory and Archaeology. Cambridge: Polity Press.

Shanks, M. \& C. Tilley, 1987b. Re-constructing Archaeology: Theory and Practice. Cambridge: Cambridge University Press.

Simpson, M., 1979. Dying, Death and Grief: a Critical Bibliography. New York (NY) \& London: Plenum Press.

Simpson, M., 1987. Dying, Death and Grief: a Critical Bibliography. New edition. Pittsburgh: University of Pittsburgh Press.

Stone, L., 1977. The Family, Sex and Marriage in England 1500-1800. London: Weidenfeld \& Nicholson.

Tarlow, S., 1995. Metaphors of Death in Orkney 1560-1945 AD. Unpublished Ph.D. thesis, University of Cambridge.

Thomas, J., 1991. Rethinking the Neolithic. Cambridge: Cambridge University Press.

Treherne, P., 1994. Technologies of the Body and Self: Personal 'Toilet Articles' in the Nordic Early Bronze Age. Unpublished M.Phil. thesis, University of Cambridge.

Vernant, J.-P., 1991. A 'beautiful death' and the disfigured corpse in Homeric epic, in Mortals and Immortals: Collected Essays, ed. F. Zeitlin. Princeton (NJ): Princeton University Press, 50-74.

Waugh, E., 1948. The Loved One. Harmondsworth: Penguin.

Whittick, A., 1946. War Memorials. London: Country Life.

Winter, J., 1977. Britain's 'Lost Generation' of the First World War. Population Studies 31, 449-66.

Winter, J., 1995. Sites of Memory, Sites of Mourning: the Great War in European Cultural History. Cambridge: Cambridge University Press.

Wurst, L., 1991. 'Employees must be of moral and temperate habits': rural and urban elite ideologies, in McGuire \& Paynter (eds.), 125-49. 